\title{
THE PUMA IN THE CENTRAL MOUNTAINS AND GREAT PLAINS A SYNOPSIS
}

JAY W. TISCHENDORF, American Ecological Research Institute - AERIE, Box 380, Fort Collins, Colorado, and F. ROBERT HENDERSON, Cooperative Extension Service, Call Hall, Kansas State University, Manhattan, Kansas, USA.

Puma populations are well documented and well studied in the mountainous regions of Utah, Colorado, Wyoming, and other western states. $1,3,12,15,16$ The Puma is widely known as Cougar or Mountain Lion. Rugged forested regions are classic habitat for this large North American cat. $^{32}$

In non-montane areas of these states, however, the status of this highly adaptable felid is questionable. Even more uncertain is the extent and nature of the species' occurrence in the provinces of Saskatchewan and Manitoba, and in the states of North and South Dakota, Nebraska, and Kansas. In these latter areas there is, for the most part, a long tradition of Puma reports. The following is a synopsis of current knowledge and recent events relating to the Puma in this region.

Saskatchewan Saskatchewan Department of Environment and Resource Management biologist Wayne Runge writes, "In recent times the occurrence of the Cougar in Saskatchewan was first verified in 1948. In this case, one animal was taken by trapper Joe Fournier in the Pasquia Hills. This specimen is now in the Museum of Natural History in
Regina [now the Royal Saskatchewan Museum]" (W. Runge, pers. comm.).

Runge continues "Cougars very likely lived in Saskatchewan prior to 1948, and it is very likely that their existence extends uninterrupted all the way back to the population(s) documented for the pre-settlement period (pre-1800)."

"During the past 20 years Cougar sightings have been made sporadically throughout the southern nalf of the province. In most cases the animals were associated with drainage systems or blocks of upland woody cover, or in some instances the southern portions of the provincial boreal forest."

Runge estimates a provincial Puma population of 20-100 individuals (W. Runge, pers. comm.). The species is protected throughout the province. Comprehensive information on Saskatchewan Pumas can be found in the works of the late Tom White, architect and self-taught biologist, especially his landmark 1982 report Saskatchewan Cougar - Elusive Cat. ${ }^{27}$

Manitoba Sporadic, unverified 
reports of Puma kills extend back to 1879, when one was apparently taken in the Pembina Hills near North Dakota. The other accounts stem almost exclusively from the Brandon and Birtle-Riding Mountain areas. $^{30}$

On Christmas Day 1973, a Puma was killed on a farm outside Stead, a small town $35 \mathrm{mi}$. northeast of Winnipeg. This cat, a two-year-old male, was the first authenticated record for the province and it vindicated the unverified sightings of many people who, over the years, had reported seeing large, tawny, long-tailed cats. The Stead specimen's skin and skull are maintained at the Manitoba Museum of Man and Nature. ${ }^{30}$

One cannot discuss Manitoba Pumas without mentioning the work of Robert Nero, well known for his Great Grey Owl work, and mammalogist Robert Wrigley. Their 1982 book, Manitoba's Big Cat, a follow-up to a lengthy 1977 Canadian Field- Naturalist paper, is the definitive compendium on Pumas in the province..$^{20,30}$

Though some mammalogists question the existence of the Manitoba Puma population - Nero and Wrigley estimated the presence of up to 50 animals - the species is fully protected and Puma reports continue to be made to Manitoba Museum and Department of Natural Resources (DNR) staff at a rate of 10-50 annually. ${ }^{13}$

Minnesota and Wisconsin In addition to the above mentioned reports, the presence of a small Manitoba population is further supported by at least four decades of intermittent but verified Puma reports in northern Minnesota and growing numbers of reports from northern Wiscon$\sin ^{4,14,17,23,31}$ Indeed, based on these records and numerous other unconfirmed but reliable reports, the DNR's of both of these states believe their states have, at times, small, resident populations of Pumas.

North Dakota There are very few Pumas in North Dakota, and almost certainly no resident, breeding population. The most recent Puma specimen was taken between 31 December 1990 and 4 January 1991. This cat, an 81-lb., one-yearold female, was shot by Coyote hunters in a barn in Golden Valley County in the North Dakota Badlands (Steve Allen, ND Fish and Game Dept., pers. comm.). This is the most recent confirmed specimen for the state.

Generally, Puma reports received by the North Dakota Fish and Game Department are infrequent and tend to come from west of the Missouri River and from the Turtle Mountains in the north central part of the state.

In terms of prey and habitat, the potential for increased Puma presence in North Dakota undoubtedly exists. Laws to protect the species were enacted 1 July 1992 (Lou Huffman, pers. comm.).

South Dakota The historical presence of Pumas in South Dakota, particularly in the Blacks Hills, is well substantiated. $^{32}$ In December 1957, a Puma was killed at Elk Mountain, and today a resident population is presumed to exist within the Black Hills-Custer National Forest-Custer State Park complex (Eileen Dowd and Ted Benzon, South Dakota Game, Fish and Parks Dept., pers. comm). ${ }^{10,18}$

In 1974, while conducting aerial hunting operations for Coyotes, biologist Lou Huffman observed an 


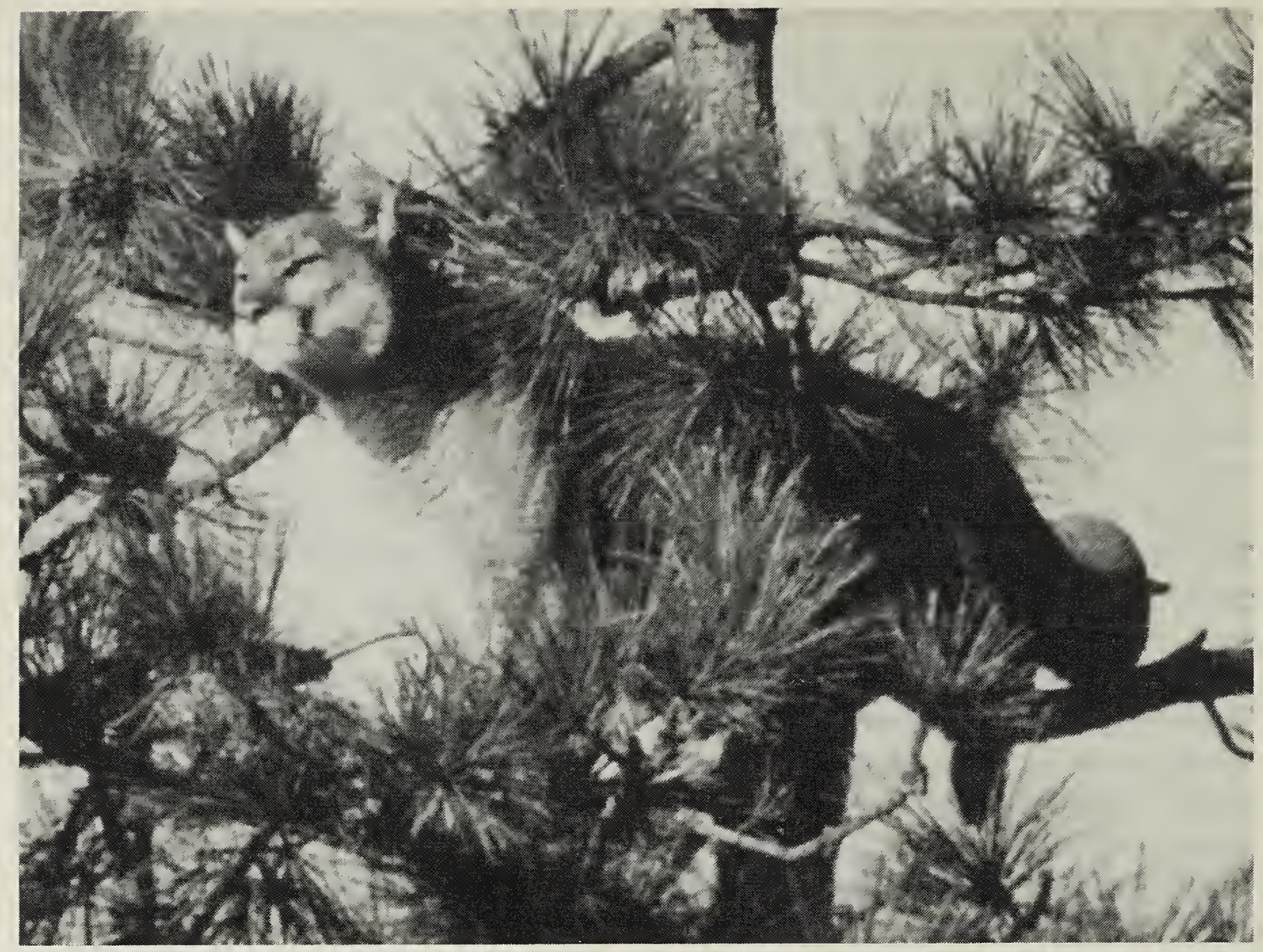

Cougar.

Wayne Lynch

adult Puma and its kitten along the White River near Winner (L. Huffman, pers. comm.). In December 1992, a young $90-\mathrm{lb}$. Puma was captured alive by a Coyote trapper in eastern South Dakota near Lowery (Ted Benzon, SD Game, Fish and Parks Dept., pers. comm.). It was radio-collared and released in the Black Hills. Tracking was discontinued after seven days largely due to concern over state liability if the cat were to become a depredator or nuisance animal.

Nebraska In November 1991, an 80lb. female was shot and killed in the Nebraska panhandle. ${ }^{19}$ A month later a young male was discovered near Worthington in the intensively agricultural region of southwest Minnesota. ${ }^{2}$ It was subsequently caught and translocaied to Colorado. It is quite possible that both these cats were dispersing from the isolated and presumable easily saturated Black Hills population. Another sce- nario has them originating in Wyoming or Colorado. In any case, the Nebraska cat, taken by a Dawes County deer hunter, was the state's first confirmed kill in a century. ${ }^{11}$

The species is unprotected in $\mathrm{Ne}$ braska, and though Puma reports have been made for decades, these animals are almost certainly transients. $^{21}$

Kansas The pattern is much the same in Kansas, where Puma reports persist despite the last verified Puma kill occurring in Ellis County, central Kansas, in $1904 .^{7}$

Pumas are frequently reported in eastern Kansas, a situation difficult to explain considering the nearest known populations are in Texas, New Mexico, Colorado, Wyoming, or South Dakota. Though their presence has yet to be verified, it is not unlikely that bordering Kansas there is a dispersed population of Pumas 
using a habitat complex encompassing the Ozark, Ouachita, and Mark Twain National Forests of Missouri and Arkansas. ${ }^{22,24}$

Under Kansas laws, the Puma is protected. One should refer to Gabbert and Henderson for a full discussion of the species' history and status there. ${ }^{8}$ Data gathered during preparation of this report led to the establishment of an official Puma record-keeping system by the Cooperative Extension Service at Kansas State University. Between May 1990 and August 1993, 156 purported Puma observations were tallied.

Discussion As deer populations have recovered and increased following early and mid-1900 lows, it appears there have been parallel increases in Puma numbers. Additionally, concurrent decreases in the rural human populations have opened, or reopened, Puma habitat. The phenomenon of ephemeral, or cryptic, Pumas in areas where for many years they have been thought extirpated is not new. ${ }^{28,29}$

A steadfast believer in the continued existence of the Eastern Cougar, or Panther, the late Canadian ecologist and pioneer frogmancommando Bruce Wright was vindicated in August 1993 when a set of tracks and a scat found in a forested area of east central New Brunswick were confirmed as those of a Puma. ${ }^{6}$ Though the origin of this cat will remain uncertain, the sparse settlement and remoteness of the area tend to preclude the possibility of its release or escape from captivity. Further investigation of Puma presence here and in New England is certainly merited. ${ }^{25}$

The range of the White-tailed Deer is expanding northward, and with it, that of the Puma. In the Kluane Lake region of the Yukon territory, for instance, Puma sightings are becoming more frequent, and on Alaska's Wrangell Island an adult male was shot in the fall of 1989 (Urs Breitenmoser, pers. comm., and Chris Land, Alaska Dept. of Fish and Game, pers. comm.). ${ }^{5,26}$

The same situation may be unfolding in the eastern half of suspected Puma range. In May 1992, $200 \mathrm{mi}$. south of James Bay, a Puma was shot near Lake Abitibi on the Quebec-Ontario border. Well into the boreal forest, this outpost area has for years been a hot bed of Puma reports and is closer to the historic range of the endangered Eastern Cougar, Felis concolor couguar, than that of any other race. ${ }^{9}$ The specimen, a small male, is presently being evaluated at the Canadian Museum of Man and Nature. Hopefully, a determination of the cat's genetic and subspecific status will be made.

The question of Puma subspecies - and there are upwards of 30 - is for the most part academic. Most were classified by mere handfuls of skins, skulls, and parts thereof in a time when taxonomic splitting and name dropping were vogue. ${ }^{32}$ Given the Puma's widespread historic range and its propensity for wandering, the supposed subspecific differences, often exceedingly minor, are probably only figments of small sample sizes and taxonomists' imagination. With the advent of DNA-based genetic evaluation, new light will soon be shed on this subject. This is especially important for management of endangered and pur- portedly unique subspecies like couguar (East), coryi (Florida), schorgeri (Wisconsin), browni "Yuma puma" of ArizonaCalifornia), and costaricensis (Costa Rica). 
The role of escaped or released captives is also an important factor in the issue of Pumas in areas not recently considered to be acceptable habitat. Unfortunately, there is almost no instance in which the possibility of a former captive Puma playing a role in a sighting, recolonization, or range expansion can be completely ruled out.

In Kansas, for example, 18 people are licensed to breed and sell $\mathrm{Pu}$ mas. Additionally, many individuals in Kansas maintain Pumas as pets and until recently no license for this was required, making documentation of origins and fates of such pets extremely problematic. So, sadly, people do own and breed these animals, often with very little regulation and monitoring from their regional governments. It follows that some Pumas, one way or another, eventually become feral. Such feral individuals, if they become nuisance animals or depredators, give the entire species a bad name and can negatively impact bona fide conservation and restoration efforts.

Escaped or released captives that successfully adapt to the wild, however, deserve the same treatment afforded native, wild-born Pumas or other, officially translocated, wildlife, be they otters, trout, Red Wolves, or turkeys - just as we provide full protection to the hybridized and captive-born Peregrine Falcons that today sail so many of our skies.

In any case, as the New Brunswick incident discussed above shows, each verified Puma report must be evaluated and managed individually if true objectivity is to be maintained.

It is unfortunate that in so many cases the proof-positive of Puma presence - even despite the convincing evidence of independent but unverified and thus scientifically un- acceptable sightings - comes down to a carcass in the hand. Ironically, it is often only after a Puma is killed in a jurisdiction that the species is granted official protection there.

History has repeatedly shown that where people are reporting Pumas, chances are good it is Pumas that at least some of them are seeing. Why wait to protect them?

Pumas leave distinctive signs tracks, scrapes, or scratches, kill and scat. Unfortunately, few conservation professionals in the Great Plains, Midwest, and East have experience looking for, finding and interpreting this evidence. A comprehensive field guide to Puma sign, designed for layperson, woodsman and professional alike, is badly needed.

This paper is dedicated to the memory of Thomas Frederick Randall White, Regina, Saskatchewan, 1929-1984.

1. ANDERSON, A.E., D.C. BOWDEN, and D.M. KATNER. 1992. The Puma on Uncompahgre Plateau, Colorado. Tech. Pub. 40, Colorado Division of Wildlife, Denver, Colorado. 116 pp.

2. ANONYMOUS. 1992. News-Mirror. Buffalo Lake, Minnesota.

3. BERG, R.L., L.L. MCDONALD, and M.D. STRICKLAND. 1983. Distribution of mountain lion in Wyoming as determined by mail questionnaire. Wildlife Society Bulletin 11:265-268.

4. BUE, G.T. and M.H. STENLUND. 1953. Recent records of the mountain lion, Felis concolor, in Minnesota. J. of Mammalogy 34:390-391.

5. CAHALANE, V.H. 1964. A preliminary study of distribution and numbers of Cougar, Grizzly and Wolf in North America. New York Zoological Society, Bronx, New York. 12 pp.

6. CUMBERLAND, R. 1993. Evidence of the Eastern Cougar in New Brunswick. New Brunswick Dept. of Natural Resources and Energy, Fredericton, NB. 4 pp. 
7. DILL, B. 1984. History of the mountain lion in Kansas, and a personal report of a June 1983 sighting. Unpub. manuscript, US Fish and Wildlife Service, Manhattan, Kansas. 6 pp.

8. GABBERT, A. and F.R. HENDERSON. 1990. Puma in Kansas. Cooperative Extension Service. Kansas State Univ. Manhattan, Kansas. 8 pp.

9. GERSON, H. 1986. The status of the cougar (Felis concolor Linnaeus) in Ontario, with an overview of the status in Canada. Ontario Ministry of Natural Resources. 59 pp.

10. HAFNOR, J. 1983. Lions and bears - fact or fancy. P. 60 in Black Hills believables. Lone Pine Prod., Fort Collins, Colorado. 108 pp.

11. HAYES, T. ed. 1991. Omaha, Nebraska: Mountain lion shot; first in century. Beacon Journal. Akron, Ohio. P.4-a.

12. HORNOCKER, M.G. 1992. Learning to live with mountain lions. National Geographic 182:52-65.

13. JOHNSON, C. 1990. The cougar in Manitoba. Manitoba Dept. of Natural Resources, Winnipeg. 15 pp.

14. KUYAVA, G.C. 1959. Two reports of mountain lion from Lake and Cook Counties. Flicker 31:6.

15. LINDZEY, F.G., B.B. ACKERMAN, D. BARNHURST, T. BECKER, T.P. HEMKER, S.P. LAING, C. MECHAM, and W. VANSICKLE. 1989. BoulderEscalante cougar project final report. Utah Division of Wildlife Resources, Salt Lake City, Utah. 92 pp.

16. LOGAN, K.A., L.L. IRWIN, and R. SKINNER. 1986. Characteristics of a hunted mountain lion population in Wyoming. J. of Wildlife Management 50:648-654.

17. MAGNUS, L.T. 1956. Mountain lion observation in Lake of the Woods County. Flicker 28:43-44.

18. MANN, T. (as told to Don Hipschman) 1959. The "phantom" of Elk Mountain. South Dakota Conservation Digest 26:3-5.

19. MEYER, J. 1991. Mountain lion taken in Pine Ridge. Press release. Nebraska Game and Parks Commission. Lincoln, Nebraska. $1 \mathrm{p}$.
20. NERO, R.W. and R.E. WRIGLEY. 1977. Status and habits of the cougar in Manitoba. Can. Field-Nat. 91:840.

21. NOWAK. R.M. 1976. The cougar in the United States and Canada. USDI Fish and Wildlife Service, Washington, DC and New York Zoological Society, Bronx, New York. 190 pp.

22. SEALANDER, J.A. and P.S. GIPSON. 1973. Status of the mountain lion in Arkansas. Proceedings of the Arkansas Academy of Science 27:38-41.

23. STENLUND, M. 1985 . Minnesota's golden ghost. Pp. 102-104 in Popple leaves and boot oil. Heritage North, Grand Rapids, Minnesota. 126 pp.

24. TISCHENDORF, J.W. ed. 1993. Eastern panther update, \#3. American Ecological Research Institute, Aerie, Fort Collins, Colorado. 8 pp.

25. - 1992. Cougars in new Brunswick: a preliminary search. Report No. 4. American Ecological Research Institute - Aerie, Fort Collins, Colorado. $13 \mathrm{pp}$.

26. WEDDLE, F. 1965. The ghost cats of the Yukon. Defenders of Wildlife News 40:53.

27. WHITE, T. 1982. Saskatchewan Cougar - elusive cat. Special pub. No. 14, Saskatchewan Natural History Society, Regina, SK. 80 pp.

28. WRIGHT, B.S. 1959. The ghost of North America - the story of the eastern panther. Vantage Press, New York, NY. 140 pp.

29. _ 1972 The eastern panther - a question of survival. Clarke, Irwin and Co., Toronto, ON. 180 pp.

30. WRIGLEY, R.E. and R.W. NERO. 1982. Manitoba's big cat - the story of the cougar in Manitoba. Manitoba Museum of Man and Nature, Winnipeg, MB. 68 pp.

31. WYDEVEN. A.P. 1993. Rare mammal observations 1992. Wisconsin Dept. of Natural Resources, Madison, WN. $8 \mathrm{pp}$.

32. YOUNG, S.P. and E.A. GOLDMAN. 1946. The Puma - mysterious American cat. American Wildlife Institute, Washington, DC. 358 pp. 